\title{
Born this Way?: How U.S. College Students Make Sense of the Biosocial Underpinnings of Race and Other Identities
}

\author{
Marc P. Johnston-Guerrero \\ The Ohio State University \\ U. S. A. \\ Vu Tran \\ The Ohio State University \\ U. S. A.
}

\begin{abstract}
With advances in biotechnology come potential changes in how college students may understand the nature of identity. This study explores sensemaking around the biological underpinnings of proclaimed "social" identities (e.g., race, class, and gender). Based on interviews with 34 undergraduate students recruited from two large public research universities in the United States, a conceptual model is offered to outline the general process of how students make sense of biological and/or social explanations of identity, including the role of controllability and essentialism. We discuss implications for multicultural education and teaching the "social construction" of identity in changing contexts.
\end{abstract}

KEYWORDS: higher education, biosocial sensemaking, identity, college students, race

\author{
Literature Review \\ Framing a Biosocial Construction of Identity \\ Method \\ Findings \\ Discussion and Implications \\ Limitations and Areas for Future Research \\ References \\ Author Contact
}

Multicultural educators in U.S. higher education have been tasked with helping college students become citizens within a "democratic multicultural society," often through teaching "tolerance, recognition of cultural difference, deliberation, and modes of civil discourse" (Hurtado, 2007, p. 190). This goal has been accomplished through many educational formats, including cross-cultural and social justice education. While the attention of such efforts has been on issues of power, privilege, and oppression as they relate to social identities (Zúñiga, Nagda, Chesler, \& Cytron-Walker, 2011), what appears to be missing is a more intentional focus on the concepts underlying social identities. Although U.S. higher education scholars and practitioners use the term "social identity" when teaching 
students about different dimensions of identity like race, class, and gender, they frequently overlook or discount biological factors in identity formation. Given the shifting societal contexts marked by advancements in genetics (e.g., the coding of the human genome), production of scientists (e.g., broadening participation in STEM fields), and popular fascination with DNA (Donovan, 2014; Nelkin \& Lindee, 2004; Roberts, 2011), changes are also occurring in the way that social identities are understood by college students considering these biological and technological realities.

For example, direct-to-consumer genetic ancestry testing, such as those offered by Ancestry.com, is marketed broadly and extensively on social media with such promises as "Discover if you're part Scandinavian, West African, or maybe Native American." Popular media outlets and television shows often feature the use of DNA ancestry testing to help in "finding your roots" or answer questions such as, "Who do you think you are?" The social aspects of identity have become increasingly influenced by notions of biology, particularly genetics. Are multicultural educators missing out by solely focusing on the "social" aspects of students' identities while minimizing biology? Given the ways society is seeing a "(re)biologization of race" (Omi, 2010) and other social categories (Haslam, Rothschild, \& Ernst, 2000), this paper attempts to explore the changing landscape related to biologically and socially influenced identities by showing how college students understand their constructions. Specifically, we investigate the role of biology in students' beliefs about social identities through two research questions:

1. How does biology play a role in U.S. college students' understandings of different social identities?

2. How do students make sense of biological and social explanations when making claims about the nature of identity?

\section{Literature Review}

Scholarship on identity has seemingly been separated into two camps: those who view identity as socially constructed and those who contend that sociological explanations alone are insufficient. Many higher education scholars and practitioners have aligned with the first camp in their promotion of identity as a socially constructed concept (Adams, Bell, \& Griffin, 2007; Torres, Jones, \& Renn, 2009), while biological explanations of identity have largely been rejected (McDonald, 2013; Tawa \& Kim, 2011). College students are likely to be educated about race, gender, sexual orientation, and other identities through the paradigm of "social identities" (Jones \& Abes, 2013) and social constructionism (Khanna \& Harris, 2009; Morning, 2009). Despite this fact, students maintain conceptions rooted in biological explanations of race (Johnston, 2014; Morning, 2009). As such, it is disconcerting that many scholars are dismissive of biological lines of inquiry related to identity, particularly race and gender, even though students themselves might place value on biological explanations of identity. 
Not all scholars contend that biology does not and should not inform conceptions of identity, as some have argued biology to be a meaningful component. In his research on how blind individuals make sense of race, Obasogie (2013) makes the case for the relevance of biology:

The constructionist approach to race does not take into account the growing body of evidence that social categories of race map on to biological differences that are observable at the molecular level and also explain various racial disparities in social or health outcomes. (p. 27)

This idea has been shared by other scholars. Sesardic (2010) argues that "typical attempts to disconnect the concept of race from genetics have too quickly and too uncritically been accepted by many 'race critics', including most philosophers of science who have discussed this issue" (p. 160). Similarly, Berenbaum, Blakemore, and Beltz (2011) contend that biological explanations are "dismissed on the basis of opinion alone, findings are misrepresented, unpalatable evidence ignored, and readers are left with an inaccurate impression of what it means for behavior to be influenced by biology" (p. 807).

Biological and social understandings are not always seen as mutually exclusive. For example, research on adolescence has long considered the importance of biological factors in one's development in addition to psychological and social factors (Caspi, Lynam, Moffitt, \& Silva, 1993; Halpern, Waller, Spriggs, \& Hallfors, 2006; Petersen, 1988; Shanahan, 2000). Few would question the importance of biology in the study of age identity. However, the resistance toward biological explanations of identity, particularly race, is understandable based on the disturbing history of eugenics and biological essentialism (Ordover, 2003).

Biologically essentialist beliefs relate to identity being viewed as immutable and determined, specifically caused by genes or other essence placeholders (DarNimrod \& Heine, 2011). Identity groups are then viewed as homogenous and discrete, as well as rationalized to be natural. People tend to be easily convinced by genetic attributes of identity compared with other attributes (e.g., environmental, spiritual, political), even when the genetic explanation offered is weak (Dar-Nimrod \& Heine, 2001). Thus, it is imperative to understand how college students have potentially been exposed to genetic/biological explanations through material learned in high school classes, their personal experiences, or other media such as books, movies, and television. For instance, the movie GATTACA (Niccol, 1997), which fictionalizes a future where one's life is determined by genetics at birth, has been used in science classes when discussing the possibilities and ethical dilemmas surrounding genetic technologies (Kirby, 2004). Given the troubling consequences of biologically essentialist beliefs about identity (e.g., Eugenics), and the current context of education enforcing social constructions of identity only, this study explores how students use biological explanations, social explanations, or both, in their sensemaking of identity. 


\section{Framing a Biosocial Construction of Identity}

This study is framed by theories of social identity and biosocial constructs. Jones and Abes (2013) provide an extensive review of social identity construction citing literature acknowledging the biological underpinnings of socially constructed identities. For instance, Weber (2010) argued that "although they may have biological or material referents, race, class, gender, and sexuality are not fixed properties of individuals nor of materially defined groups" (as cited in Jones \& Abes, 2013, p. 38). Furthermore, when operationalizing race, Jones and Abes (2013) acknowledged that "race is both biological and socially constructed" and argued that the social is what makes race meaningful and significant (p. 167). This theoretical approach to identity acknowledges both biological and social components, as well as qualities of fixedness and discreteness across groups. We argue that social meanings are biologically influenced and that biology is ultimately tied to the social meanings, making such qualities significant.

A biosocial approach debunks the either/or extremes of biological and social constructions of identity and argues that "implications of results from socialization perspectives are restricted without consideration of biology, and vice versa" (Berenbaum et al., 2011, p. 805). Hacking (2006) eloquently stated: "Knowledge of genetic 'identities' will forge social ones, creating new communities of shared recognition based on partial science" (p. 88). Given the lack of studies that have acknowledged both biological and social components of identity, we use a biosocial theoretical approach to inform our analysis of the data in the current study.

\section{Method}

This paper comes out of a larger mixed methods project that explored how 40 college students experienced and understood the concept of race on campus. The larger project employed a constructivist grounded theory methodology (Charmaz, 2006), in which an exploratory preliminary study focused on students' racial thinking found core categories of (a) developing diverse racial meanings, and (b) reasoning through biological race. Part of how students reasoned through the concept of race included comparing the nature of race to other social identities (e.g., gender, sexual orientation, and class). Out of the 40 total participants, 34 made these comparisons. In this study, we focus exclusively on the comparisons made in these participants' interviews. 


\section{Sample and Data Collection}

Data include semi-structured, one-on-one interviews conducted with 34 undergraduate students from two large, public, research institutions within the same state university system on the U.S. West Coast. Following IRB approval by both sites, we sent email announcements to various listservs and posted fliers around campus. Participants opted into the study by responding to the announcements. The sample included 23 women, 10 men, and 1 student who identified as genderqueer; and 15 Asian American, 8 White, 5 Latina/o, 2 African American, and 4 mixed-race students. Across both institutions, no racial group was a numerical majority, although Asian Americans were the largest racial group. The overrepresentation of Asian Americans in the study likely reflects the institutions' compositional diversity, as well as the authors' positionality as Asian Americanidentified researchers. It is also possible that Asian American participants may have felt more comfortable participating in a research study on race that was conducted by Asian American scholars. All class years were represented (1 Firstyear, 7 Sophomores, 8 Juniors, 14 Fourth-years, and 4 Fifth-years) as well as a variety of majors (ranging from engineering to linguistics). All participants received a $\$ 10$ gift card for the interviews, which ranged from 45-90 minutes.

The interviews consisted of several introductory and background questions to establish rapport, followed by a protocol modified from Morning's $(2009,2011)$ study on racial conceptions in order to focus on the context of higher education. Sample questions included asking students to open-endedly define race as well as asking them to react to a statement about whether biological races existed. In explaining the nature of race, these participants also explained the nature of other identities, providing us the opportunity to examine how students made sense of biological and social aspects of multiple dimensions of identity (Jones \& Abes, 2013). The semi-structured nature of the interview included frequent follow-up questions to better examine how students were reasoning through the complex nature of race and other identities.

\section{Data Analysis}

Data analysis consisted of open and axial coding techniques and constant comparative analyses (Charmaz, 2006; Glaser \& Strauss, 1967). Using a combination of open coding and memoing, both authors independently engaged in open coding of four interviews. Through memoing we shared our list of open codes, finding similarities and differences and beginning to collapse codes. The first author took the list of preliminary codes to apply to a second subset of data (4 interviews) to begin axial coding toward developing an initial coding scheme. This scheme was then shared with the second author and used to independently code four other interviews, noting codes that needed to be updated and codes that did 
not capture much of students' sensemaking. Coming together and memoing further, we compared the updated coding scheme to our previous coding experiences, noting any discrepancies in clarity, ultimately updating the coding scheme to one that better fit the data. As we moved forward with axial and theoretical coding, we began conceptualizing a model that seemed to capture the processes of students' sensemaking, and identifying exemplary quotes to explain the model in our findings.

We acknowledge that although the larger study followed methodological approaches to conducting a constructivist grounded theory study (Charmaz, 2006), this current study borrowed particular analytical techniques of grounded theory to make sense of the data and answer our research questions. We also acknowledge our positionalities as researchers that have influence over both data collection and interpretation. While both authors are Asian American men, the first author, who conducted all interviews, is multiracial and queer. These aspects of his identity may have influenced how participants responded to questions about race and sexual orientation. For instance, the queer student participants likely read the first author as an insider when sharing their views on sexual orientation. We share this piece of our positionality statement as a way to build in transparency of interpretations. Other methods for assessing the "goodness" of this qualitative research include adhering to our epistemological (constructivist) and methodological (grounded theory) assumptions, and working toward consensus as we moved from description to interpretation of the data (Arminio \& Hultgren, 2002; Jones, Torres, \& Arminio, 2014).

\section{Findings}

When posed with complex questions about what race is (e.g., whether or not it is socially or biologically constructed, or both), students' understandings were sometimes made clearer by comparing race to other identities like gender, sexual orientation, religion, class, age, and (dis)ability. When probed further, comparisons of different identities complicated their understanding of the biological and socially constructed nature of identities, and conveyed that different identities varied in the amount of their social constructedness. Emerging from data analysis, we found a general process for students' sensemaking around this complexity, along with two major concepts that appeared to influence their sensemaking: controllability and essentialism. This process allowed students to consider certain identities on a continuum between more biologically influenced or socially constructed, while some students exempted themselves from having an opinion when they did not have enough prior knowledge, personal experiences, or authorities to whom to defer. For ease of presenting findings, we start with the general process outlined in the Biosocial Model of Identity Sensemaking (Figure 1) that emerged from data analysis. We then discuss the components more specifically, using student quotes as evidence. 


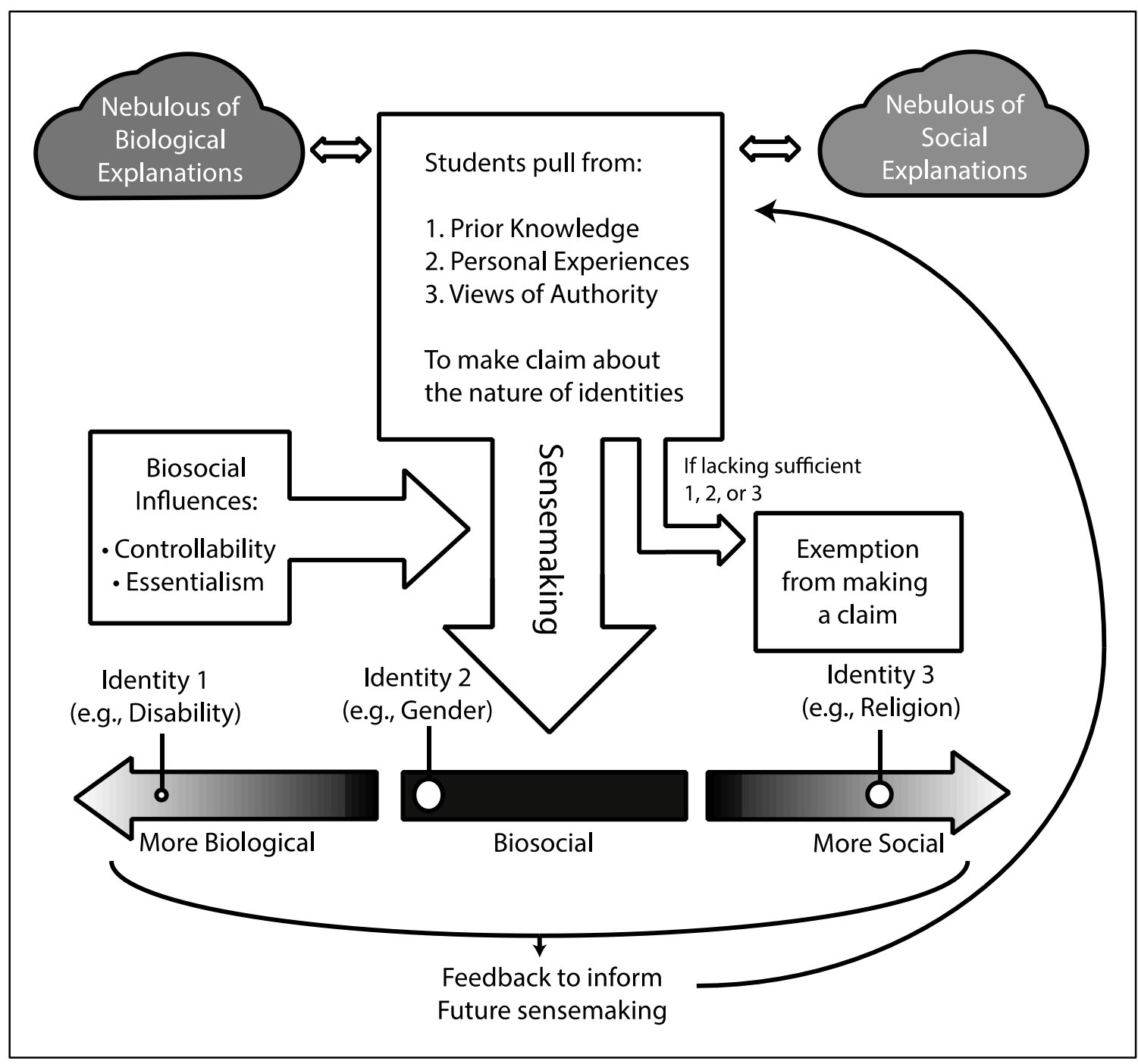

Figure 1. Biosocial model of identity sensemaking.

\section{Making Sense of the Complexity of Identities}

The model outlines how students include biological explanations for identity to varying degrees, largely depending on their understanding of biological influences informing each identity. To get to that understanding, students go through a process of sensemaking that is situated within a larger context that includes various biological and social explanations. We refer to these contexts as "nebulous" because they are often difficult to clearly identify, yet students understand that biological factors and social forces are "out there" in the world and are used to explain who we are-our identities. The model begins with students' prior knowledge, personal experiences, or views of authority figures to inform students' sensemaking of identities. By pulling together their knowledge, experiences, and authoritative views, they grapple with comparing and contrasting 
identities and the ways they are biologically and socially constructed. For instance, Fred, a Filipino American senior majoring in chemistry, shared how his personal experience and learning influenced his view that all identities were a mix of both the biological and social, but he ultimately made sense of them as socially constructed:

[Identity is] a mix of both. I personally think it's how people embrace themselves and how they construct these themselves. Because I know for me it's more of like the social construct because that's what my parents taught me. It's what I saw on TV. It's what I'm seeing as a personal experience.... I know for me it's just how I taught myself and.... Just coming here [to college], l've learned that the biological construct really doesn't matter because we are all one and the same. So then I'm focusing more on the social construct side because that's where I believe it all stems from.

Fred's example demonstrates how his prior knowledge (e.g., what he was taught by his parents) and his personal experiences allowed him to recognize biological explanations but make and support his claim about the socially constructed nature of different identities. Additionally, his reference to individuals being "all one and the same" echoes expert claims of genetic similarities between individuals of different groups.

In contrast to Fred, Amanda, a multiracial, fifth-year student and physiology major shared how her learning from science classes influenced her sensemaking around the biological nature of gender and sexuality:

I would think there are biological differences as well or like genetic differences because like there is different levels of hormones and all these other factors that go into gender as just - then just like girls have these body parts and boys have these... and we actually, in one of my classes... we were looking at like slices of like the brain and there is like this center in the brain and that like gay men had a smaller something, I forget, it's probably like the corpus callosum... and it was like smaller in like gay men as opposed to like straight men...we were like just talking about that in class.

Amanda recognized the biological underpinnings of gender and sexuality due to biological concepts she learned in classes, whereas Fred seemingly has made up his mind that biology does not have a place in understanding identity. Her direct references to body parts and hormones are indicative of her view of biology being inseparable from identity.

As outlined in the model, students draw upon prior experiences and knowledge to inform their sensemaking of identities, yet they could also defer to the views of authority figures (e.g., researchers, teachers) when making their claims. Melissa, a junior majoring in history who identified as White, shared her thoughts on sexual orientation being biologically influenced based on views of her science professors:

I have heard, I know that a lot of my like science professors have stated it, and of course l'm going to trust them over like some guy on CNN, but that 
sexual orientation is biological and so that's where I think that. Then also, we live in a pretty Christian country... it's like the Christians have this idea of like, "you are born the way you are, like be happy with it" or whatever and then they are very opposing of men sleeping with men. And I mean, I guess you can't really change someone's mind about it, but if it's like proving that's biological, it's like why would you hate someone then?

Melissa seemed to recognize the social forces at play in influencing different explanations of sexuality, yet used the authority of her science professors in making sense of the biological underpinning of sexuality.

Next in the model, students' sensemaking of identity is moderated by their implicit or explicit views on controllability and essentialism, which are discussed in more detail below. Through this process, students can compare different identities with respect to how biologically or socially constructed they are, and eventually place them on a continuum between being more biological or more social, or both -- biosocial. We posit that there is a middle region of the continuum that represents more of a biosocial approach to identity, where both biological and social explanations are important for sensemaking. In addition to variance in where identities might be placed along the continuum, students may vary in how confident they were on that placement. In our model, confidence is depicted based on the density of the point on the biological-social continuum. A more diffuse mark represents a lower level of confidence (depicted by identity 1 ), while a more dense point represents a higher level of confidence (depicted by identity 3 ).

Additionally, the model accounts for students who exempt themselves from making a claim because they lack prior knowledge, personal experiences, or authority figures to defer to. From our participants, this exemption was particularly noticeable when considering more controversial identity dimensions like sexual orientation, as Rachael, a White sophomore majoring in biology, stated,

I don't know [about sexual orientation]. I think like a lot of people nowadays think that it's biological. But, I'm not really sure and like being a Christian it's kind of like, you know, you're like told that's it's not okay and stuff, so, I don't know, I'm not really sure, it's definitely like a hot topic, I guess.

Rachael's articulation of being unsure may come from not having thought too deeply about the issue because she has not encountered it or learned much about it. Her reference to Christianity offers one source of an authority figure, but her lack of knowledge on the issue may weaken her tendency to defer to it in resolving this controversial topic for herself.

\section{Biological Influences on Sensemaking}

Participants tended to equate biology with genetics, and when applied to identities, genetics influenced the extent to which identities were thought of as immutable or controllable. Such immutability related to the underlying essences of identities and groups that mostly manifested in physical aspects of the body. 
Natasha, a senior majoring in geography who identified as Indian American, argued,

I think race is, your genes determine what color your hair is, what color your skin is, plus your genetic-your physical make up is determined by your genes....So if you want to call a race just physical characteristics and just kind of like those kinds of things, then yeah it's determined by your genes.

Natasha also felt that genetics influenced other social categories, like gender:

Gender theoretically is completely genetically chosen in terms of chromosomes, but then you can rework your, at least your physical gender and even mentally how you feel. But your genes are still your genes. It can still be like, complete surgery done and everything, but you are still genetically one thing, and you were born that way and you'll stay that way.

Here, Natasha's sensemaking was influenced by how much control she believed one has over identity. In the case of gender, Natasha argued that genes are beyond one's locus of control and factor into gender identity, consistent with concepts of genetic essentialism. However, other physical aspects such as hair, dress and makeup are malleable and dependent on an individual's choice on how they represent themselves.

This juxtaposition of choice and genetics seemed to echo debates about nature and nurture, particularly regarding discourse about being born a certain way. Choice of identity was also equated with how much control one had over a category, as Corey, an Asian American sophomore and sociology major, stated,

I feel like some of the categories are things we have control over and some of them aren't. Like people generally get to choose like what religion they believe in. But you can't choose like what sex you are or like what like, what your DNA or like ethnic makeup is.

Haley, a Vietnamese American junior and neuroscience major, similarly juxtaposed religion and race when discussing choice:

Religion is something that you can kind of choose, it's not something that like you are born with, like you have a say in that religion, or well some religions I guess... but like race for me, it's something that you're born with, and it's not really something you can change. You can't really change your race. But with like religion and other aspects you can like choose what it is you want to do and like it can change.

Haley's contrasting of race and religion conveyed the significance of being born with certain attributes and traits. Her beliefs evidently show that people are born with a race, but are not necessarily born with religion. Attributing characteristics at birth may result in more influence of biological explanations on identity sensemaking.

In this process of sensemaking, students are using what they know about both biological factors and social forces in comparing different identities. This 
sensemaking was most apparent among the several students who identified as both persons of color and queer. Bob, a Chicana/o studies senior, reasoned,

As someone who, as a Latino and a Chicano, I'm like, "no, race is not biological. You should see more." But then as a Catholic queer I want to say "yeah, it is biological. I was born this way, I didn't choose this." ...But then the same thing could go for people of color. They could say, "I didn't choose this." So then when they say I didn't choose this are they referring to the fact that they didn't choose to be subordinated or they didn't choose to be this certain color, so then it's biological.

In this instance, Bob's claimed identities as a Chicano, Catholic, queer man - and the learning and experiences attached to those identities - offered him both biological and social lenses to make sense of the complexities of identity. This sense of having "choice" and "choosing" was important for contemplating the biosocial nature of identity.

\section{Considering Identities along the Biosocial Continuum}

The perspectives that participants shared demonstrate how students' understanding of different social identities varied on the extent to which they were more biological or more social. Like Corey and Haley's examples, religion was often used as a measuring point to compare other social identities, because across participants, religion was viewed as more social, influenced by the perspective that one has control or choice over religious identity. For instance, Rachael stated, "Religion. I mean obviously that can be influenced by your parents and stuff. But it's not biological, it's basically what you choose and like what you believe." Rachael's use of "obviously" also demonstrated her confidence level in making this claim.

Participants in our study tended to reference certain identities using biological or social explanations. Overall, the more socially constructed identities included class, religion, race, and gender. The more biologically influenced identities included age, sexual orientation, and disability, although this varied. For instance, Marie, an Indian American senior majoring in human development, thought all social identities were generally "socially constructed" except age: "I think age is more biological just because it is a distinct measure about how old you are, but you could look a lot older, you could look a lot younger and that can be totally different." The observation of age being a measureable identity speaks to the immutability of chronological age as a biological construct, yet Marie also references to how young or old someone could look. The controllability of one's age appearance might reveal that age could potentially be something that is actually a mixture of biological and social constructions.

Sexual orientation was the murkiest of the social identities students discussed, as Corey stated, "I've heard different arguments about [sexual orientation], like it's biological. I've also heard that it's a choice and I don't really 
know. I don't think anyone really knows like which it is." Corey represents an example of how students might exempt themselves from having to make a claim about certain identities. Natasha shared, "Sexual orientation is one big murky, in terms of the genetic part, people haven't figured out what exactly makes people gay, straight, bi, whatever, but I do think... it's more hardwired... than class or religion." It is possible that participants experienced the most conflict on whether to reference social or biological explanations of understanding sexual orientation due to a lack of prior knowledge, personal experience, or influential authorities specifically on the nature of sexual orientation. This gap can be filled by multicultural educators.

In the model, the consideration and placement (along with confidence level behind such claims) of different identities along the continuum serve as a feedback loop to inform or revise students' knowledge and experiences. Student determinations about how biosocial a particular identity is may serve to revise their knowledge, experiences, or views of authority when asked to make sense of other identities, or that same identity at a later time. Although this aspect of the model was not necessarily found among our participants because our study was not longitudinal, we included this piece as a possibility. As lan, a Black-identified senior majoring in ethnic studies, shared,

My personal opinion about sexuality, I think, l've dealt with it for a while, because I think everyone experiences their sexuality differently. I see it as a gradient, like, you could be at any point. But I am a queer person who has known or experienced my queerness since I was a child. So, a lot of people don't experience that. Some people find out in college. Some people find out later on in life. But my personal opinion is that I think that no one is born with a sexuality. I feel like your experiences have shaped what you're attracted to... I don't think sexuality is biological. I think in this world, like the whole mentality of, like, boot straps, and like what's innate to you, and hard work is - the people's experiences are left out.

lan's own experiences around his sexuality informed his sensemaking about sexuality not being biological, but also he realized how that may look different for people who do not experience their sexual identity until later in life. As this process happens, students' experiences, knowledge, and views of authorities likely change to inform their future sensemaking.

\section{Discussion and Implications}

In this study, we sought to explore how U.S. college students' sensemaking of identity is informed by both biological and social explanations. We found that our participants contemplated identities beyond ideas of social constructionism by including biological reasons underpinning identity. Yet, aside from a few exceptions, they tended to see biological and social explanations as mutually exclusive. Given the range of understandings that college students have of identity, 
we argue that a both/and approach outlined in our Biosocial Model is imperative for multicultural educators to help students in understanding the complexities of identity.

Our findings support the claim made by Khanna and Harris (2009) that "many Americans continue to view race as biologically real and racial categories as meaningful divisions in the population" (p. 370). Our model suggests that the activities and strategies multicultural educators employ to teach about the social construction of identity should not dismiss the prior knowledge, experiences, and views of authorities that college students bring into their learning experience, which may be based on or supported by biological understandings.

A biosocial approach to identity helps educators in supporting students to explore different identity-based questions. The common identity-based question of "Who are you?" has typically been answered by focusing solely on social aspects of identity. But perhaps students are also connecting this question to a similar question of "What are you?" when contemplating the biological underpinnings of identity. This "What are you?" question is commonly asked of multiracial individuals (Johnston \& Nadal, 2010; Kellogg \& Liddell, 2012; Renn, 2004). It is also likely asked of anyone who does not fit neatly into social categories, for instance, gender non-conforming people (Tran \& Glazer, 2012). Physicality plays a role as one's outward appearance (Obasogie, 2013) and behavior-both influenced by biology and individual choices-are judged by observers who question not just who one is but what one is. Ultimately, students have a level of choice in how they control their identities, but society often does not allow such choices to be fluid. In the case of multiracial individuals, such fluidity in changing identity across time or different situations can be a source of prejudice and discrimination (Museus, Lambe, \& Hawamata-Ryan, 2015). Similar prejudices are often applied to bisexual people as well (McLean, 2008).

As multicultural educators, our goal should be to help students better understand just how complex identity can be. Without incorporating biological aspects of identity in the multicultural curriculum, educators are missing out on an important aspect of how students are making sense of who they are. Yet focusing exclusively on biological reasoning also misses the mark. For example, by narrowing down sexual orientation to genetics, we limit students' agency in deciding how to be in the world and who they love. Although biology could be seen as an answer to homophobic challenges to "choosing" a "gay lifestyle," as for instance when NIH geneticist Dean Hamer sought out to find a "gay gene" (Ordover, 2003), biology cannot be the only answer. Such focus on biology offers clearer answers to questions of "What are you?" that actually constrain answers to "Who are you?" questions. If biology is finitely relied upon, identities become immutable and essentialist in nature, and less controllable in the minds of students.

Literature on essentialism has thoroughly documented the consequences of essentialist views on identity. As Haslam (2011) explains, "Essentialism deepens social divides, making differences appear large, unbridgeable, inevitable, unchangeable, and ordained by nature" (p. 819). Essentialist beliefs can also cause individuals to deny a human essence towards outgroups while favoring 
individuals within groups (Haslam, Bastian, Bain, \& Kashima, 2006). Similarly, Tawa and Kim (2011) found that people with higher intergroup anxiety may affirm their racial identity by asserting that racial groups are biologically and socially different. Finally, individuals' understandings of biology can impact the way in which they negotiate treatment for psychological issues (Haslam, 2011).

By incorporating both biological and social components of identity, our model addresses concerns of essentialism in a way that can be useful for multicultural educators when working with students to develop more complex understandings of identity. It is not enough to say that race, or any other identity, is socially constructed. We must take more nuanced approaches to teaching about identities by considering prior knowledge, personal experience, and references to authority regarding biology. For example, identity-based activities could be supplemented by accessing what students know and believe about race, whether it is socially or biologically constructed, and use their shared group knowledge as a starting basis for further unpacking the biosocial nature of race.

We also encourage multicultural educators to contemplate the roles of essentialism and controllability in their students' sensemaking. Although essentialism is often viewed in biological terms, there are points in history where strategic essentialism has been used in a more social nature. For instance, groups may emphasize a common essence to increase group size and representation during social movements (Lipsitz, 2003). In terms of controllability, the sense that one has some control or choice, yet may be influenced by biology, can also be helpful for contemplating a biosocial approach to identity. As was the case in Bob's quote earlier, choosing a racial identity as Chicano allowed him further confidence that race was not biological. Yet, the intersection of his queer and Catholic identities created a tension that could be alleviated by arguing for a lack of choice in terms of his sexual orientation. By incorporating both the biological and social, essentialism and controllability can be useful concepts for helping students make sense of identity from a biosocial approach. Ultimately, having access to and being able to use both biological and social explanations may help students make sense of the full complexities of identity.

\section{Limitations and Areas for Future Research}

There are several limitations of this study that help inform areas of future research. We note that the larger project in which this study was situated focused specifically on race, which likely influenced who volunteered to participate as well as the centrality of race in students' sensemaking about identities overall. Future research should explore more intently and specifically the question of biosocial explanations of identities without priming race as the starting point for participants. The findings show that students vary in their confidence of claiming whether identities are influenced by biology, social contexts, or both. However, this was not necessarily the focus of our questioning and thus we were unable to probe more specifically about what contributed to various confidence levels. Future studies 
could employ a more quantifiable measure of students' confidence levels regarding biological or social explanations and variance based on different identities. Future research of this nature may provide useful information for trends and tendencies in which identities may be more likely to be understood as biological or socially constructed. Additionally, this study only captured a snapshot of students' conceptions of identities, and does not show development of sensemaking across time because data were collected at only one time point. Development and changes over time could be explored in future longitudinal studies. The prominence of identity controllability as a point of reference for students provides another point of focus for future research. Finally, subjective measures on which identities can be more or less controlled may have bearing on beliefs about biological and social explanations of identities.

\section{References}

Adams, M., Bell, L. A., \& Griffin, P. (Eds.). (2007). Teaching for diversity and social justice (2nd ed.). New York, NY: Routledge.

Arminio, J. L., \& Hultgren, F. H. (2002). Breaking out from the shadow: The question of criteria in qualitative research. Journal of College Student Development, 43(4), 446-60.

Berenbaum, S. A., Blakemore, J. E. O., \& Beltz, A. M. (2011). A role for biology in gender-related behavior. Sex Roles, 64(11-12), 804-825. doi:10.1007/s11199-011-9990-8

Caspi, A., Lynam, D., Moffitt, T. E., \& Silva, P. A. (1993). Unraveling girls' delinquency: Biological, dispositional, and contextual contributions to adolescent misbehavior. Developmental Psychology, 29(1), 19-30. doi:10.1037/0012-1649.29.1.19

Charmaz, K. (2006). Constructing grounded theory: A practical guide through qualitative analysis. Thousand Oaks, CA: Sage Publications.

Dar-Nimrod, I., \& Heine, S. J. (2011). Genetic essentialism: On the deceptive determinism of DNA. Psychological Bulletin, 137(5), 800-818. doi:10.1037/a0021860

Donovan, B. M. (2014). Playing with fire? The impact of the hidden curriculum in school genetics on essentialist conceptions of race. Journal of Research in Science Teaching, 51(4), 462-496. doi:10.1002/tea.21138

Glaser, B. G., \& Strauss, A. L. (1967). The discovery of grounded theory: Strategies for qualitative research. Chicago, IL: Aldine.

Hacking, I. (2006). Genetics, biosocial groups and the future of identity. Dædalus (Fall), 81-95. 
Halpern, C. T., Waller, M. W., Spriggs, A., \& Hallfors, D. D. (2006). Adolescent predictors of emerging adult sexual patterns. Journal of Adolescent Health, 39(6), 926.e1-926.e10. doi:10.1016/j.jadohealth.2006.08.005

Haslam, N. (2011). Genetic essentialism, neuroessentialism, and stigma: Commentary on Dar-Nimrod and Heine. Psychological Bulletin, 137(5), 819-824. doi:10.1037/a0022386

Haslam, N., Bastian, B., Bain, P., \& Kashima, Y. (2006). Psychological essentialism, implicit theories, and intergroup relations. Group Processes \& Intergroup Relations, 9(1), 63-76. doi:10.1177/1368430206059861

Haslam, N., Rothschild, L., \& Ernst, D. (2000). Essentialist beliefs about social categories. British Journal of Social Psychology, 39(1), 113-127. doi:10.1348/014466600164363

Hurtado, S. (2007). Linking diversity with the educational and civic missions of higher education. The Review of Higher Education, 30(2), 185-196. doi:10.1353/rhe.2006.0070

Johnston, M. P. (2014). The concept of race on campus: Exploring the nature of college students' racial conceptions. Journal of College Student Development, 55(3), 225-242. doi:10.1353/csd.2014.0023

Johnston, M. P., \& Nadal, K. L. (2010). Multiracial microaggressions: Exposing monoracism in everyday life and clinical practice. In D. W. Sue (Ed.), Microaggressions and marginality: Manifestation, dynamics and impact (pp. 123-144). New York, NY: Wiley \& Sons.

Jones, S. R., \& Abes, E. S. (2013). Identity development of college students: Advancing frameworks for multiple dimensions of identity. San Francisco, CA: Jossey-Bass.

Jones, S. R., Torres, V., \& Arminio, J. (2014). Negotiating the complexities of qualitative research in higher education: Fundamental elements and issues (2nd ed.). New York, NY: Routledge.

Kellogg, A. H., \& Liddell, D. L. (2012). "Not half but double": Exploring critical incidents in the racial identity of multiracial college students. Journal of College Student Development, 53(4), 524-541. doi:10.1353/ csd.2012.0054

Khanna, N., \& Harris, C. A. (2009). Teaching race as a social construction: Two interactive class exercises. Teaching Sociology, 37(4), 369-378.

Kirby, D. A. (2004). Extrapolating race in GATTACA: Genetic passing, identity, and the science of race. Literature and Medicine, 23(1), 184-200. doi:10.1353/Im.2004.0006

Lipsitz, G. (2003). Noises in the blood: Culture, conflict, and mixed race identities. In M. Coronado, R. P. Guevarra, J. Moniz, \& L. F. Szanto (Eds.), Crossing lines: Race and mixed race across the geohistorical divide (pp. 19-44). Santa Barbara, CA: Multiethnic Student Outreach/UCSB. 
McDonald, B. (2013). The reproduction of biological "race" through physical education textbooks and curriculum. European Physical Education Review, 19(2), 183-198. doi:10.1177/1356336X13486052

McLean, K. (2008). Inside, outside, nowhere: Bisexual men and women in the gay and lesbian community. Journal of Bisexuality, 8(1-2), 63-80. doi:10.1080/15299710802143174

Morning, A. J. (2009). Toward a sociology of racial conceptualization for the $21 \mathrm{st}$ century. Social Forces, 87(3), 1167-1192. doi:10.1353/sof.0.0169

Morning, A. J. (2011). The nature of race: How scientists think and teach about human difference. Berkeley, CA: University of California Press.

Museus, S. D., Lambe, S. A., \& Hawamata-Ryan, T. (2015). Qualitative examination of multiracial students' coping responses to experiences with prejudice and discrimination in college. Journal of College Student Development 56(4), 331-348. doi:10.1353/csd.2015.0041

Nelkin, D., \& Lindee, M. S. (2004). The DNA mystique: The gene as a cultural icon. Ann Arbor, MI: University of Michigan Press.

Niccol, A. (1997). GATTACA. Columbia Pictures.

Obasogie, O. (2013). Blinded by sight: Seeing race through the eyes of the blind. Palo Alto, CA: Stanford University Press.

Omi, M. (2010). "Slippin' into darkness": The (re)biologization of race. Journal of Asian American Studies, 13(3), 343-358. doi:10.1353/jaas.2010.0001

Ordover, N. (2003). American eugenics: Race, queer anatomy, and the science of nationalism. Minneapolis, MN: University of Minnesota Press.

Petersen, A. C. (1988). Adolescent development. Annual Review of Psychology, 39, 583-607. doi:10.1146/annurev.ps.39.020188.003055

Renn, K. A. (2004). Mixed race students in college: The ecology of race, identity, and community on campus. Albany, NY: SUNY Press.

Roberts, D. (2011). Fatal invention: How science, politics, and big business recreate race in the twenty-first century. New York, NY: The New Press.

Sesardic, N. (2010). Race: A social destruction of a biological concept. Biology \& Philosophy, 25(2), 143-162. doi:10.1007/s10539-009-9193-7

Shanahan, M. J. (2000). Pathways to adulthood in changing societies: Variability and mechanisms in life course perspective. Annual Review of Sociology, 26, 667-692.

Tawa, J., \& Kim, G. S. (2011). How does biological belief in race relate to our feelings towards in-group and out-groups?: A cognitive dissonance framework. Current Research in Social Psychology, 16(4), 1-10.

Torres, V., Jones, S. R., \& Renn, K. A. (2009). Identity development theories in student affairs: Origins, current status, and new approaches. Journal of College Student Development, 50(6), 577-596. doi:10.1353/csd.0.0102 
Tran, S. V., \& Glazer, E. M. (2012). Transgenderless. Harvard Journal of Law \& Gender, 35, 399-423.

Weber, L. (2010). Understanding race, class, gender, and sexuality ( $2^{\text {nd }}$ ed.). New York, NY: Oxford University Press.

Zúñiga, X., Nagda, B. R. A., Chesler, M., \& Cytron-Walker, A. (2011). Intergroup dialogue in higher education: Meaningful learning about social justice. (Vol. 4). San Francisco, CA: Jossey Bass.

\section{Author Contact}

Marc P. Johnston-Guerrero: Guerrero.55@osu.edu

The Ohio State University, 301 Ramseyer Hall, 29 W. Woodruff Ave., Columbus, $\mathrm{OH} 43210$, USA

Vu Tran: tran.430@osu.edu

The Ohio State University, 301 Ramseyer Hall, 29 W. Woodruff Ave., Columbus, $\mathrm{OH} 43210$, USA 